\title{
Correction to: TRAP1 suppresses oral squamous cell carcinoma progression by reducing oxidative phosphorylation metabolism of Cancer-associated fibroblasts
}

\author{
$\mathrm{Li} \mathrm{Xiao}^{1,2+}{ }^{+}$, Qiannan $\mathrm{Hu}^{3+}{ }^{+}$, Yanshuang Peng ${ }^{1}$, Kaiyue Zheng ${ }^{1}$, Ting Zhang ${ }^{1}$, Lianjie Yang ${ }^{1}$, Zhi Wang ${ }^{3}$, \\ Wanrong Tang ${ }^{1}$, Jie Yu' ${ }^{1}$, Qian Xiao ${ }^{1}$, Dandan Zhang ${ }^{1}$, Weifang Zhang ${ }^{1}$, Chanjuan He' ${ }^{1}$, Dengxun Wu' \\ Yanyan Zheng ${ }^{4^{*}}$ and Ying Liu ${ }^{1 *}$
}

Correction to: BMC Cancer 21, 1329 (2021)

https://doi.org/10.1186/s12885-021-09049-z

Following publication of the original article [1], the authors noticed that the funding statement was missing. The funding statement is supplied below:

This research was supported by the Pre-research Grant for National Natural Science Foundation of China from North Sichuan Medical College (CBY19-YZ08 to Y. Liu), Clinical and Basic Research Overlapping Fusion Foundation of China from Affiliated Hospital of North Sichuan Medical College (2021LC010 to Y. Liu).
Published online: 29 December 2021

\section{Reference}

1. Xiao L, Hu Q, Peng Y, et al. TRAP1 suppresses oral squamous cell carcinoma progression by reducing oxidative phosphorylation metabolism of Cancer-associated fibroblasts. BMC Cancer. 2021;21:1329. https://doi.org/ 10.1186/s12885-021-09049-z.

\begin{abstract}
Author details
'Department of Stomatology North Sichuan Medical College, Afliated Hospital of North Sichuan Medical College, Nanchong, China. ${ }^{2}$ Department of Stomatology, Nan Chong Central Hospital, Second Clinical Medical College of North Sichuan Medical College, Nanchong, China. ${ }^{3}$ Guanghua School of Stomatology, Guangdong Provincial Key Laboratory of Stomatology, Stomatological Hospital, Sun Yat-Sen University, Guangzhou, China. ${ }^{4}$ School of Basic Medical Sciences, North Sichuan Medical College, Nanchong, China.
\end{abstract}

The original article can be found online at https://doi.org/10.1186/s12885021-09049-z.

*Correspondence: liuying08_nsmz@163.com;yanyzheng@163.com

${ }^{+} \mathrm{Li}$ Xiao and Qiannan Hu contributed equally to this work.

${ }^{1}$ Department of Stomatology North Sichuan Medical College, Afliated

Hospital of North Sichuan Medical College, Nanchong, China

${ }^{4}$ School of Basic Medical Sciences, North Sichuan Medical College,

Nanchong, China

Full list of author information is available at the end of the article

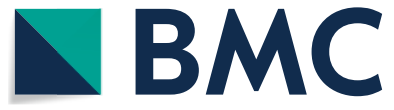

(c) The Author(s) 2021. Open Access This article is licensed under a Creative Commons Attribution 4.0 International License, which permits use, sharing, adaptation, distribution and reproduction in any medium or format, as long as you give appropriate credit to the original author(s) and the source, provide a link to the Creative Commons licence, and indicate if changes were made. The images or other third party material in this article are included in the article's Creative Commons licence, unless indicated otherwise in a credit line to the material. If material is not included in the article's Creative Commons licence and your intended use is not permitted by statutory regulation or exceeds the permitted use, you will need to obtain permission directly from the copyright holder. To view a copy of this licence, visit http://creativecommons.org/licenses/by/4.0/. The Creative Commons Public Domain Dedication waiver (http://creativeco mmons.org/publicdomain/zero/1.0/) applies to the data made available in this article, unless otherwise stated in a credit line to the data. 